\title{
Genetic Diversity Analysis of cpDNA in Turkish Abies Taxa
}

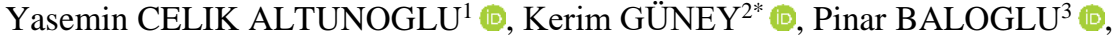 \\ Mehmet Cengiz BALOGLU ${ }^{1}$
}

${ }^{1}$ Kastamonu University- Faculty of Engineering and Architecture- Department of Genetics and Bioengineering, Kastamonu, TURKEY

${ }^{2}$ Kastamonu University - Faculty of Forestry, Department of Forest Engineering- Kastamonu, TURKEY

${ }^{3}$ Kastamonu University - Research and Application Center, Kastamonu, TURKEY

${ }^{*}$ Corresponding Author: kguney@kastamonu.edu.tr

Received Date: 12.04.2020

Accepted Date: 01.03.2021

\section{Abstract}

Aim of study: Five Abies taxa naturally distributed in Turkey. Abies nordmanniana has three subspecies and A. cilica has two subspecies. In this study, we aimed to show phylogenetic relationships both in Turkish taxa and in other Abies taxa from around the world based on cpDNA regions, $\operatorname{trn} R-\operatorname{trn} N$ and rps 18-rpl20 regions.

Material and methods: Following CTAB-based DNA isolation method, the relevant fir DNA regions were amplified and sequenced. Phylogenetic trees were constructed using maximum likelihood method with 1000 bootstrap replicates.

Main results: It was difficult to make distinctions among the Turkish Abies taxa based on the sequenced DNA regions. Based on rps18-rpl20 phylogenetic tree, some members of Abies cilicica subsp. isaurica, A. nordmanniana subsp. equi-trojani and A. cilicica subsp. cilicica were in the same clade with A. spectabilis and A. densa; However, some members of A. nordmanniana subsp. bornmuelleriana, A. cilicica subsp. isaurica and A. nordmanniana subsp. equi-trojani were placed in a clade with $A$. alba placed near Turkey and A. amabilis known from North America.

Highlights: This study provides new insights into the distribution of cpDNA variation in Abies species in Turkey and the genetic variation between firs in Turkey and the rest of the world.

Keywords: Fir, Molecular Taxonomy, Chloroplast DNA Region

\section{Türk Göknar Taksonlarında Genetik Çeşitlilik Analizleri}

Öz

Çalışmanın amacı: Beş Abies taksonu Türkiye'de doğal olarak dağılmıştır. Abies nordmanniana' nın üç alt türü ve $A$. cilica 'nın iki alt türü vardır. Bu çalışmada, cpDNA bölgeleri, trnR-trnN ve rps 18-rpl20 bölgelerine göre hem Türk taksonlarında hem de dünyanın diğer Abies taksonlarında filogenetik ilişkileri göstermeyi amaçladik.

Materyal ve yöntem: CTAB metodu ile DNA izolasyonunun ardından ilgili göknar DNA bölgeleri çoğaltılmış ve dizilenmiştir. Filogenetik ağaçlar, 1000 tekrarlı maximum likelihood (maksimum olabilirlik) yöntemi kullanılarak oluşturulmuştur.

Temel sonuçlar: Türkiye'deki göknar taksonları arasında bu bölgeler bakımından ayrım yapmak zor gözükmektedir. rps18-rpl20 dizileri temelindeki filogenetik ağaca dayanarak, bazı Abies cilicica subsp. isaurica, A. nordmanniana subsp. equi-trojani ve A. cilicica subsp. cilicica üyeleri $A$. spectabilis ve $A$. densa ile aynı sınıfta yer alırken, bazı A. nordmanniana subsp. bornmulleriana, A. cilicica subsp. isaurica ve $A$. nordmanniana subsp. equi-trojani üyeleri ise Türkiye'ye yakın yayılış gösteren $A$. alba ve Kuzey Amerika'da yayılışı bilinen A. amabilis ile aynı sınıfta yer almıştır.

Araştırma Vurgulart: Mevcut çalışma, Türkiye'deki göknar türleri arasında cpDNA çeşitliliğinin dağılımına ve Türkiye göknarları ile dünyada yayılış gösteren diğer göknar türleri arasındaki genetik çeşitliliğe yeni bir ışık tutmaktadır.

Anahtar Kelimeler: Göknar, Moleküler Taksonomi, Kloroplast DNA Bölgesi 


\section{Introduction}

Firs (Abies Mill.) are coniferous trees in the Pinaceae family which includes 51 species that are native to the Northern Hemisphere. They distribute naturally in the temperate and boreal regions of the Northern Hemisphere and are mainly found in the mountainous regions of North America, Central America, Europe, North Africa and Asia (Himalaya, South China, and Taiwan) ( $\mathrm{Li}, 1975)$. The genus is restrained to the mountainous areas in the subtropical and temperate latitudes of the Northern Hemisphere (Farjon, 1990).

Fir tree species are found in many forest areas of Turkey. Five taxa, which are placed in two fir tree species (Abies nordmanniana and Abies cilicica) are naturally distributed in Turkey. Three of these five taxa are endemic. These taxa are Abies nordmanniana subsp. nordmanniana (distributed in the North of Kizilırmak in East Black Sea region), A. nordmanniana subsp. bornmuelleriana (distributed from the West of Kizılırmak to Uludağ in the east Blacksea region), Abies nordmanniana subsp. equitrojani (distributed between the Çanakkale, Balıkesir and Bursa), Abies cilicica subsp. isaurica (distributed in the middle and West Taurus Mountains in the South Anatolia region) and A. cilicica subsp. cilicica (distributed in the East Taurus Mountains in the South Anatolia region). However, A. nordmanniana subsp. bornmuelleriana and A. nordmanniana subsp. equi-trojani cannot be morphologically distinguished. Therefore, these two taxa were combined under the name of "Kazdagi Fir" in "Turkey Plant List (Vascular Plants)" (Güner et al., 2000; Güner et al., 2012).

Molecular genetic methods are widely used to analyze the conserved regions of the genome (Ateş, 2011). Molecular phylogenetic analysis using DNA sequence data enables molecular botanists to better define various taxonomic categories. Nuclear (nDNA), chloroplast (cpDNA) and mitochondrial (mtDNA) DNA sequences have been utilized to evaluate phylogenetic relationships in plants (Suyama et al., 2000; Xiang et al., 2004; Tozkar et al., 2009; Semerikova et al., 2011; Aguirre-Planter et al., 2012). However, some cpDNA regions are more informative and useful than other DNA regions for phylogenetic reconstructions (Liang, 1997). In addition, non-coding DNA regions might be more significant because of their rapid evolution than coding DNA regions. This property of non-coding DNA regions causes more variable characters and these DNA regions more useful for better construction and resolution of the phylogenetic tree (Wang et al., 1999).

Although there are many studies on the morphological classification of fir tree species (Kormutak et al., 2004; Hansen et al., 2005; Ziegenhagen et al., 2005; Xiang et al., 2009), a small number of molecular phylogenetic studies in the literature have examined Abies taxa in Turkey. These studies focused on the isozyme variation in a limited number of Anatolian fir populations (Şimşek, 1992; Gülbaba et al., 1996). To date, chloroplast matK, some trn regions, and nuclear ITS DNA regions have been examined to determine the molecular differentiation of Turkish fir tree populations (Ateş, 2011; Özdemir Değirmenci, 2011; Tayanç et al., 2013). Analyses of chloroplast $\mathrm{rbcl}$ and mitochondrial nad5-4 regions were limited to Mediterranean firs (in the South Anatolia region) which were compared with other fir species from around the world (Kormutak et al., 2004; Ziegenhagen et al., 2005). In addition, microsatellite markers were also evaluated to uncover the genetic diversity of the fir populations in Turkey (Hansen et al., 2005; Kaya et al., 2008; Hrivnák et al., 2017; Tayanç et al., 2013).

In this study, we aim to show phylogenetic relationships in Turkish fir taxa based on two non-coding cpDNA markers, i.e. trnR-trnN and rps18-rpl20. In addition, we used other fir species from previous phylogenetic studies to show taxonomic and phylogenetic position of the Turkish taxa in large phylogeny.

\section{Material and Methods \\ Plant Material}

Samples of fir taxa distributed in Turkey were investigated to determine their phylogenetic relationships (Güner et al., 2012). The morphological characteristics of 
taxa were used to identify different members of the genus Abies. Studied specimens were identified using Flora of Turkey (Davis,
1965). The geographical locations of sampled Turkish Abies taxa are shown in Table 1.

Table 1. Geographical locations of sampled Turkish Abies taxa

\begin{tabular}{|c|c|c|}
\hline Sample name & Altitude (m) & Coordinate \\
\hline Abies cilicica subsp. isaurica-1 & 1.119 & 36S 0415577 - UTM 4075471 \\
\hline Abies cilicica subsp. isaurica-3 & 1.182 & 36S 0415601 - UTM 4075497 \\
\hline Abies cilicica subsp. isaurica-4 & 1.189 & 36S 0415610 - UTM 4075480 \\
\hline Abies cilicica subsp. isaurica-6 & 1.216 & 36S 0415164 - UTM 4075536 \\
\hline Abies cilicica subsp. isaurica- 8 & 1.232 & 36S 0415168 - UTM 4075502 \\
\hline Abies cilicica subsp. isaurica-9 & 1.415 & 36S 0419208 - UTM 4075834 \\
\hline Abies cilicica subsp. isaurica-10 & 1.413 & 36S 0419194 - UTM 4075801 \\
\hline Abies nordmanniana subsp. nordmanniana-1 & 1.800 & 37T 0732683 - UTM 4557703 \\
\hline Abies nordmanniana subsp. nordmanniana-2 & 1.864 & 37T 0732503 - UTM 4557508 \\
\hline Abies nordmanniana subsp. nordmanniana-5 & 1.768 & 37T 0732252 - UTM 4558371 \\
\hline Abies nordmanniana subsp. bornmuelleriana-2 & 2.023 & 36T 0560422 - UTM 4545271 \\
\hline Abies nordmanniana subsp. bornmuelleriana-3 & 2.025 & 36T 0560421 - UTM 4545209 \\
\hline Abies nordmanniana subsp. bornmuelleriana-5 & 1.992 & 36T 0560561 - UTM 4545721 \\
\hline Abies nordmanniana subsp. bornmuelleriana-10 & 1.938 & 36T 0561995 - UTM 4546679 \\
\hline Abies nordmanniana subsp. bornmuelleriana-11 & 1.903 & 36T 0562577 - UTM 4546607 \\
\hline Abies nordmanniana subsp. equi-trojani-1 & 844 & 35S 0507652 - UTM 4418903 \\
\hline Abies nordmanniana subsp. equi-trojani-2 & 814 & 35S 0507706 - UTM 4419155 \\
\hline Abies nordmanniana subsp. equi-trojani-5 & 797 & 35S 0507521 - UTM 4419451 \\
\hline Abies nordmanniana subsp. equi-trojani-7 & 784 & 35S 0506998 - UTM 4419749 \\
\hline Abies nordmanniana subsp. equi-trojani-8 & 782 & 35S 0506979 - UTM 4419750 \\
\hline Abies nordmanniana subsp. equi-trojani-10 & 765 & 35S 0506695 - UTM 4419740 \\
\hline Abies cilicica subsp. cilicica-1 & 1.500 & 36S 0710704 - UTM 4150712 \\
\hline Abies cilicica subsp. cilicica-5 & 1.396 & 36S 0710727 - UTM 4151006 \\
\hline Abies cilicica subsp. cilicica-10 & 1.275 & 36S 0710158 - UTM 4153077 \\
\hline
\end{tabular}

DNA Isolation, PCR Amplification and Sequence Analysis

A modified cetyl trimethylammonium bromide (CTAB)-based method was used to isolate DNA from fresh needles (SaghaiMaroof et al., 1984). RNA from the extracted DNA solution was removed by RNAse enzyme $(2 \mathrm{mg} / \mathrm{mL})$ at $37{ }^{\circ} \mathrm{C}$ for $30 \mathrm{~min}$. Concentration and purity of DNA were calculated using MultiscanGo Spectrophotometer (Thermo Scientific, USA). In addition, the DNA quality was checked by $2 \%$ agarose gel and stored at $80^{\circ} \mathrm{C}$ until use.

PCR reactions included $1.5 \mathrm{mM} \mathrm{MgCl}_{2}$, 1.25 U Taq DNA polymerase enzyme, $5 \mu \mathrm{L}$ 10x PCR buffer, $5 \mu \mathrm{L} 2 \mathrm{mM}$ dNTP, 25 $\mathrm{pmol} / \mu \mathrm{L}$ of each gene's specific forward and reverse primer, $100 \mathrm{ng}$ of template DNA and distilled water to achieve a final volume of $50 \mu \mathrm{L}$. After testing for amplification efficiency, $\quad \operatorname{trn} \mathrm{R}-t r n \mathrm{~N}$ and rps 18 -rpl20 cpDNA regions were amplified by PCR.
Reaction conditions for the $\operatorname{trn} \mathrm{R}-\operatorname{trn} \mathrm{N}$ region were as follows: initial denaturation at $95{ }^{\circ} \mathrm{C}$ for $5 \mathrm{~min}$ and denaturation at $95^{\circ} \mathrm{C}$ for $1 \mathrm{~min}$, annealing at $61.4{ }^{\circ} \mathrm{C}$ for $1 \mathrm{~min}$ and extension at $72{ }^{\circ} \mathrm{C}$ for $1 \mathrm{~min}$ which was repeating 35 times, then final extension at $72{ }^{\circ} \mathrm{C}$ for 7 min. After the initial denaturation step at 95 ${ }^{\circ} \mathrm{C}$ for $5 \mathrm{~min}$, the following three steps were repeated for 35 times for the rps 18-rpl20 region: denaturation at $95{ }^{\circ} \mathrm{C}$ for $1 \mathrm{~min}$, then annealing at $50.1{ }^{\circ} \mathrm{C}$ for $1 \mathrm{~min}$ and extension at $72{ }^{\circ} \mathrm{C}$ for $1 \mathrm{~min}$, then final extension step was at $72{ }^{\circ} \mathrm{C}$ for $7 \mathrm{~min}$. The primer sequences used were as follows: $\operatorname{trn} \mathrm{R}-\operatorname{trn} \mathrm{N}-\mathrm{F}$ 5'GCCTGTAGCTCAGAGGATTA3', trnRtrnN-R 5'TCCTCAGTAGCTCAGTGGTA 3', and rps 18-rpl20F 5'AGTCGATTTATTAGTGAGCA3', rps 18-rpl20R

5'CTTCGTCGTTTGTGGATTAC 3' (Wang et al., 1999; Suyama et al., 2000). Amplification efficiency was checked with agarose gel electrophoresis and visualized by 
gel imaging system (Vilbor Lourmat, France).

Forward and reverse sequence reads were compared for the most accurate DNA sequence in the studied DNA regions. PCR product purification and DNA sequencing were performed by Refgen Biotechnology (Ankara University, Teknokent, Ankara). ABI 310 Genetic Analyzer User' s Manual was used for sequence analysis. Sequencing was performed using the Big Dye Cycle Sequencing Kit (Applied Biosystems) with a ABI 310 Genetic Analyzer (PE Applied Biosystem, USA) automatic sequencer with forward and reverse primers of the relevant cpDNA regions.

\section{Phylogenetic Tree Analysis}

Finch TV software (Geospiza Inc.) was used to visualize DNA sequence results. SnapGene software (from GSL Biotech; available at snapgene.com) was used for contig forward and reverse sequences. Sequences obtained from trnR-trnN and rps18-rpl20 sub-regions and sequences retrieved from NCBI were combined and analyzed to understand genetic diversity among Abies taxa. A phylogenetic tree was constructed by the maximum likelihood method with bootstrap analysis for 1000 replicates and JTT (Jones-Taylor-Thornton) substitution model after multiple sequence alignments by ClustalW using the MEGA 6 program (Tamura et al., 2013). For alignment analysis, ClustalW was used according to following parameters: pairwise alignment gap opening $=15$, gap extension $=6.6$ and multiple alignment gap-opening $=15$, gap extension $=6.7$, delay divergent sequences $=$ $30 \%$ and transition weight $=0.5$. Alignments were controlled and visually examined. Gaps in the aligned sequence data were considered as missing data. Pairwise distances between Abies taxa distributed in Turkey and pairwise distances between Turkish Abies members and Abies members from around the world were compared. Phylogenetic trees were displayed using interactive Tree Of Life software (iTOL) (http://itol.embl.de) (Letunic \& Bork, 2016). Turkish fir taxa were marked with $\boldsymbol{\nabla}$.

Keteleeria davidiana (JN935765.1) and Picea abies (AJ001025.1) were used as outgroups in the constructed phylogenetic trees (Semerikova \& Semerikov, 2014). The total $\operatorname{trn} \mathrm{R}-\operatorname{trn} \mathrm{N}$ sequences of 14 fir species and total rps18-rpl20 sequences of 21 fir species were obtained from the NCBI database and used to evaluate phylogenetic relationships between fir species in Turkey and those from around the world (Table 2).

Table 2. $t r n \mathrm{R}-t r n \mathrm{~N}$ and $r p s 18-r p l 20$ sequences retrieved from NCBI.

\begin{tabular}{llll}
\hline \multicolumn{2}{c}{ trnR-trnN Sequences } & \multicolumn{2}{c}{ rps18-rpl20 Sequences } \\
\hline Species Name & Accession Numbers & Species Name & Accession Numbers \\
\hline A. fraseri & AB029699.1 & A. numidica & AB019938.1 \\
\hline A. yuanbaoshanensis & JF276098.1 & A. fabri & AB029709.1 \\
\hline A. lasiocarpa & AB029703.1 & A. firma & AB029711.1 \\
\hline A. holophylla & AB029700.1 & A. homolepis & AB029714.1 \\
\hline A. fabri & AB029696.1 & A. amabilis & JN935712.1 \\
\hline A. forrestii & JF276116.1 & A. alba & JN935710.1 \\
\hline A. fargesii & AB029697.1 & A. recurvata & JN935726.1 \\
\hline A. mariesii & AB029704.1 & A. fraseri & AB029712.1 \\
\hline A. chensiensis & JF276103.1 & A. balsamea & JN935713.1 \\
\hline A. nephrolepis & JF276111.1 & A. bracteata & JN935711.1 \\
\hline A. firma & AB029698.1 & A. vejarii & JN935731.1 \\
\hline A. grandis & FJ514487.1 & A. sibirica & KC597631.1 \\
\hline A. iowiana & FJ514486.1 & A. guatemalensis & JN935748.1 \\
\hline A. concolor & FJ514485.1 & A. hickelii & JN935733.1 \\
\hline & & A. concolor & KC597675.1 \\
\hline & & A. religiosa & JN935740.1 \\
\hline
\end{tabular}


Table 2 (Continued)

\begin{tabular}{llll}
\hline \multicolumn{2}{c}{$\boldsymbol{t r n R} \mathbf{R}-\boldsymbol{t r n} \mathbf{N}$ Sequences } & \multicolumn{2}{c}{ rps 18-rpl20 Sequences } \\
\hline Species Name & Accession Numbers & Species Name & Accession Numbers \\
\hline & A. grandis & JN935717.1 \\
\hline & A. durangensis & JN935755.1 \\
\hline & A. densa & KC597651.1 \\
\hline & A. spectabilis & KC597650.1 \\
\hline & A. cilicica & KC597667.1 \\
\hline
\end{tabular}

\section{Results and Discussion}

Turkish Abies taxa were classified in previous studies but there were inconsistences in the taxonomy because of the variable and complex morphological features of fir species. The trnR-trnN sequence analysis showed that, the total length of this region was 823 bp and GC content was $45.5 \%$. Computed pairwise (p) distances between the studied samples ranged between 0.000 and 0.077 (Supplementary Table 1). All Turkish fir taxa were in the same clade of the phylogenetic tree (Figure 1). Considering that the phylogenetic tree was constructed by the maximum likelihood method and low $p$ distance values, it is difficult to make distinctions among Turkish Abies taxa members based on this cpDNA region. In the Türkiye Bitkileri Listesi (Damarl1 Bitkiler (Güner et al. 2012), A. nordmanniana subsp. bornmuelleriana and $A$. nordmanniana subsp. equi-trojani were combined. Our findings support this taxonomic treatment based on the low $p$ distance values compared with $\mathrm{p}$ distance values among the other Turkish fir taxa (Supplementary Table 1).

In addition, Abies taxa in Turkey were compared with other fir species from around the world to elucidate their phylogenetic relationship (Figure 2). The $\mathrm{p}$ distance values ranged between 0.000 and 1.227 (Supplementary Table 2). A grouping was observed between these groups. Abies concolor, A. grandis and A. iowiana were in the same clade (gray branch), mainly distributed around North America. A. nordmanniana subsp. nordmanniana members were in a different clade with some members of A. cilicica subsp. isaurica and A. cilicica subsp. cilicica in a one subgroup and A. nordmanniana subsp. bornmuelleriana and A. nordmanniana subsp. equi-trojani members in another subgroup. Other fir species aggregated in a different clade (yellow branch). The reason for this aggregation might be the absence of cpDNA trnR-trn $\mathrm{N}$ sequences from NCBI database in trees which are distributed in mainly Asia region.

The rps 18-rpl20 regions of cpDNA were compared between Turkish fir taxa and other fir species from around the world (Figure 3). The total length of this region was $513 \mathrm{bp}$ and its GC content was $33.6 \%$. According to the phylogenetic tree, Abies taxa members were closer to each other in the clade and low $\mathrm{p}$ values (varied between 0.000 and 0.063) promoted this aggregation (Supplementary Table 3). Two main clusters appeared when Turkish fir taxa and other fir species from around the world were compared (Figure 4). The p distance values were varied between 0.000 and 0.599 (Supplementary Table 4). A. nordmanniana subsp. nordmanniana was in the same cluster (green branch) as $A$. numidica. In another clade, different subgroups were observed. According to these subgroups, some members of A. cilicica subsp. isaurica, A. nordmanniana subsp. equi-trojani and $A$. cilicica subsp. cilicica were in the same clade (pink branch) as A. spectabilis (East Himalayan Fir) and A. densa (Bhutan Fir) which are known as a variety of $A$. spectabilis (A. spectabilis var. densa). However, some members of $A$. nordmanniana subsp. bornmulleriana, A. cilicica subsp. isaurica and Abies nordmanniana subsp. equi-trojani were found in the clade (yellow branch) with $A$. alba (European Silver Fir), which is distributed near Turkey and A. amabilis (Pacific Silver Fir) which is distributed in the Pacific Northwest of North America. Our chloroplast rps18-rpl20 region results indicate that fir species exposed to similar 
climate conditions aggregate in the same phylogenetic tree branch.

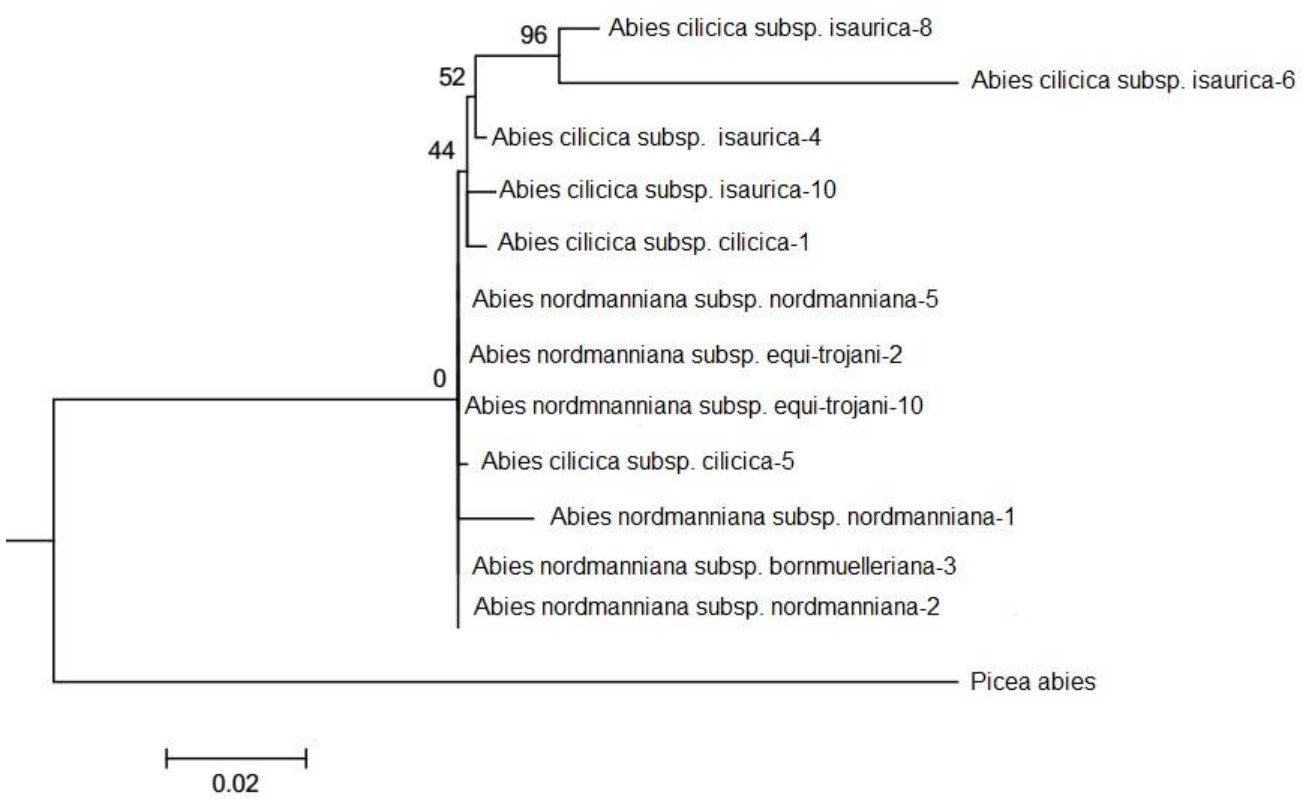

Figure 1. Phylogenetic tree based on the sequence of $t r n$ R-trnN DNA region among Turkish fir taxa members

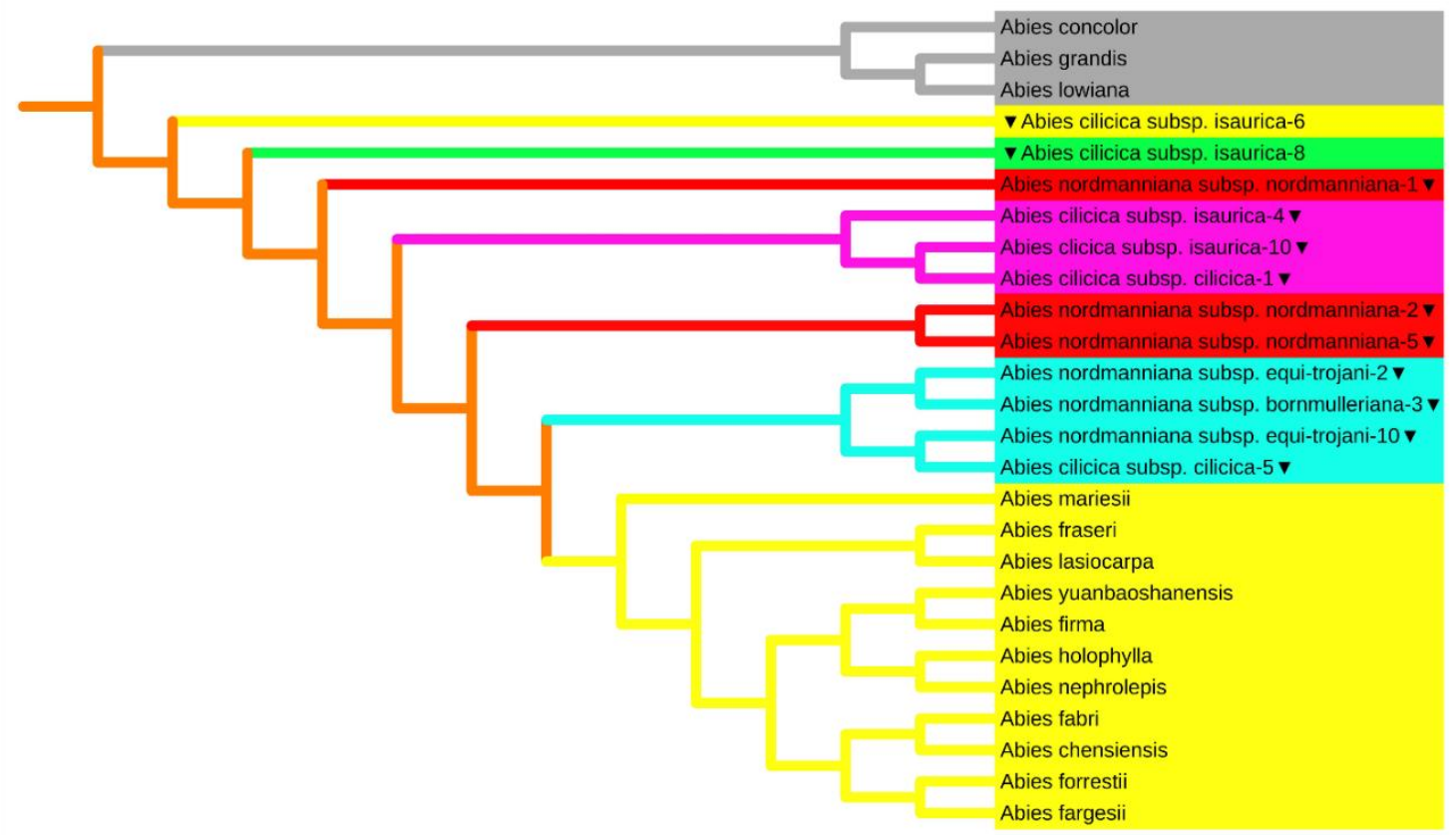

Figure 2. Phylogenetic tree based on the sequence of $t r n$ R-trnN DNA region among Turkish fir taxa members and other fir species from around the world 


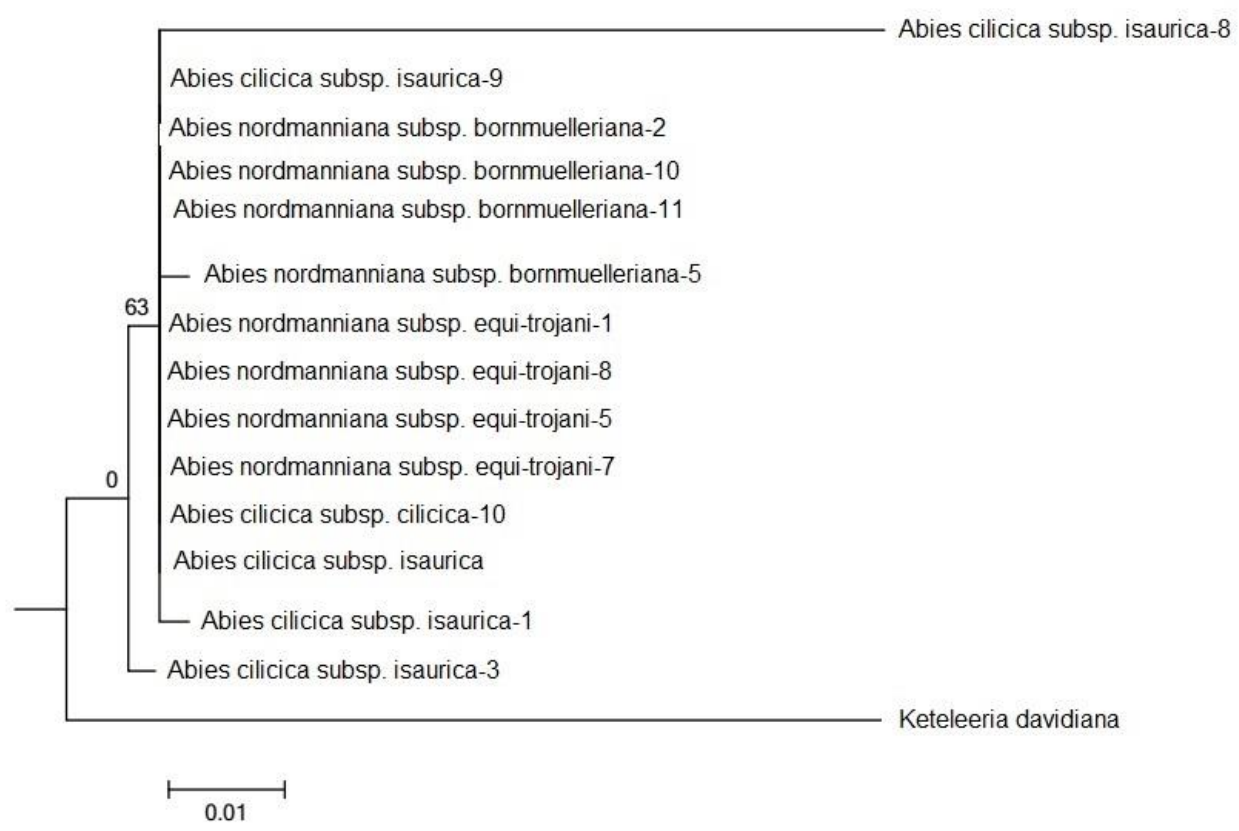

Figure 3. Phylogenetic tree based on the sequence of rps18- rpl20 DNA region of Turkish fir taxa members.

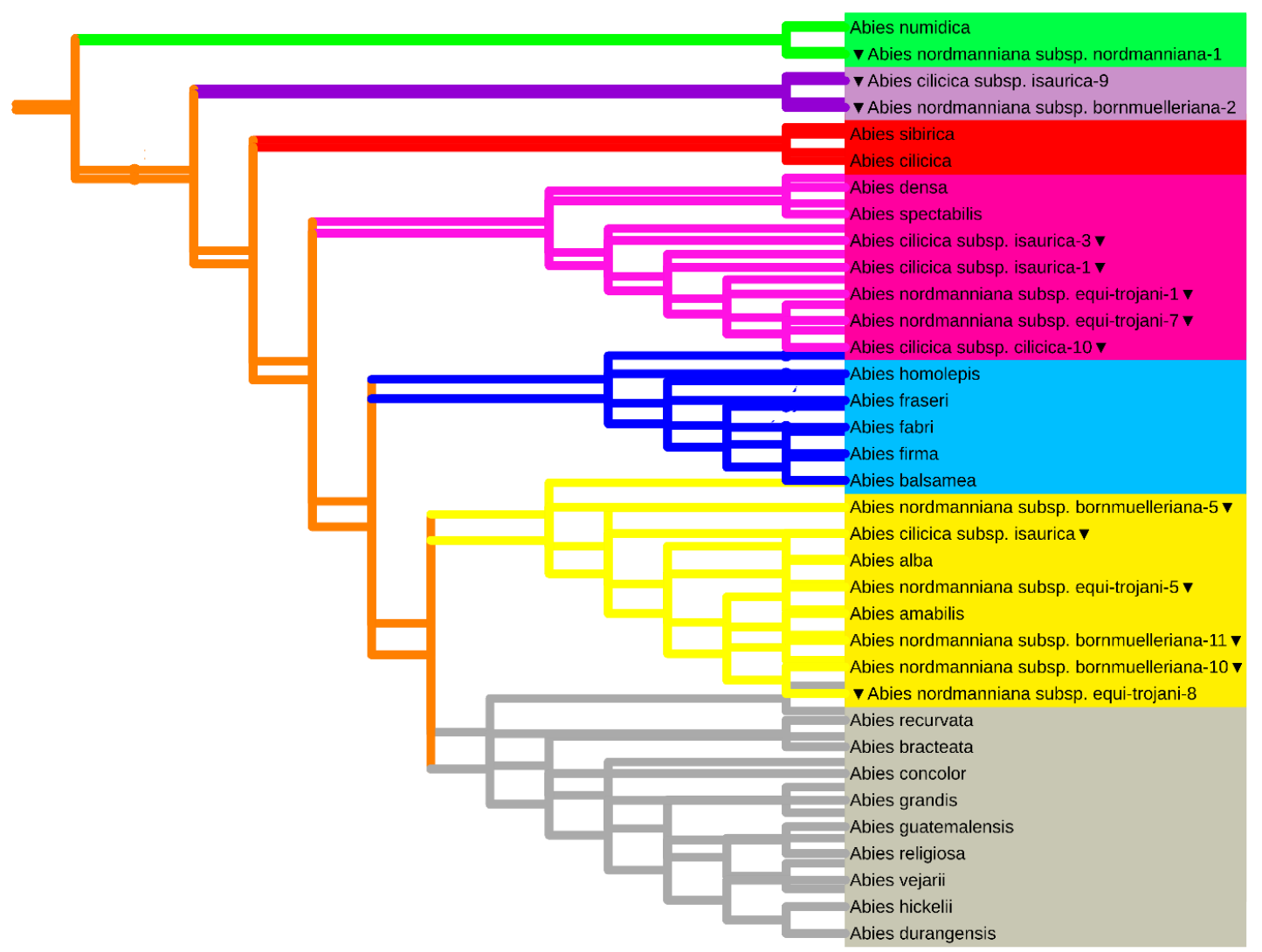

Figure 4. Phylogenetic tree based on the sequence of rps18-rpl20 DNA region of Turkish fir taxa members and other fir species from around the world. 
A genetic study of eight classified Mediterranean and one North American fir species shown that North American species (A. concolor) had the most divergent haplotypes (Parducci \& Szmidt, 1999). According to a study conducted by Kormutak et al. (2004) Mediterranean firs including closely related species differed from both Asian and North American firs based on PCR-RFLP analysis of eight genes from cpDNA. In this study, Kormutak et al. (2004) reported that Mediterranean fir species has the lowest level polymorphism. In another study, Asian, North American and Mediterranean fir species were phylogenetically classified based on $t r n \mathrm{~L}$ and $t r n \mathrm{~F}$ region sequences. The Mediterranean fir species (European) A. alba and $A$. nordmanniana differed from other fir species based on their tandem repeat types (Isoda et al., 2000). In addition, the sequence analysis of the trn $\mathrm{L}$ region of Turkish fir taxa revealed the existence of a single clade, which includes Turkish-European fir species. In the same study, Turkish fir species were aggregated and separated from AsianAmerican fir species in a phylogenetic tree based on their $\operatorname{trn} \mathrm{F}$ sequence analysis (Özdemir Değirmenci, 2011). A similar aggregation of Turkish fir species was also observed in our phylogenetic tree based on the sequences of the $t r n \mathrm{R}-\operatorname{trn} \mathrm{N}$ regions. Another important finding was made by comparing the matK1 region sequence of Turkish fir species. All Turkish fir taxa and A. numidica (Algerian fir) that grow in the Mediterranean phytogeographic region were found in the same clade, whereas other fir species from around the world dispersed into various phylogenetic clades (Ateș, 2011). In this study, A. nordmanniana subsp. nordmanniana was observed in a group with A. numidica based on the sequences of rps18- rpl20. A possible explanation for this might be their similar ecological requirements. Another important finding was that A. cephalonica (Greek Fir) which is closely related to $A$. nordmanniana (distributed in Northern Turkey) (Fady et al., 1992) was the closest species to the Turkish fir taxa with low distance rates (0.008) based on the ITS region sequence data (Tayanç et al., 2013). However, studied DNA regions in these last three studies were conserved and no differences were observed among Turkish fir taxa members (Ateş, 2011; Özdemir Değirmenci, 2011; Tayanç et al., 2013). Therefore, these results are in line with those of the previous studies. Xiang et al. (2009) analyzed internal transcribed spacer (ITS) region for 31 Abies species to examine phylogenic classification of the genus. Small and large sub-repeats were identified for Pinaceae and Abies, respectively. Four major groups, (1) Western North American monotypic section, (2) Eastern Asian-North American lineage, (3) Western North America group including species from Mexico and Eastern Asia and (4) Eurasian lineage group, were determined based on ITS regions. These results are consistent with data obtained from our study, although relationship among the four major clades remained unconvincingly resolved. This combination of findings supports the conceptual premise that Turkish fir members are in same phylogenetic clade when cpDNA or nDNA regions are used to construct a phylogenetic tree. However, fir taxa in Turkey phylogenetically differ from firs distributed in the Mediterranean and European regions and were commonly found in a distinct clade according to their cpDNA regions. Interestingly, our study shows that based on rps18-rpl20 cpDNA, some members in Turkish fir taxa are in the same clade as A. amabilis located in the Pacific Northwest of North America.

\section{Conclusion}

Previous studies on fir species in Turkey have focused on their morphological differences and there are limited data on their molecular phylogenetic relationships. The current study provides new insights into the distribution of cpDNA variation for Abies taxa in Turkey and examines the genetic variation between Turkish fir species and other fir species distributed around the world. Based on two cpDNA markers, Turkish Abies taxa are not separated from one another. This may stem from recent divergence among the taxa and indicate their common ancestor. Therefore, further studies may shed lighter on the classification of Abies by comparing the maternally inherited 
mtDNA and nDNA at low taxonomic level, which was suggested by previous biogeographic studies in coniferous species.

\section{Ethics Committee Approval N/A}

\section{Peer-review}

Externally peer-reviewed.

\section{Author Contributions}

Conceptualization: Y.Ç.A., K.G., M.C.B.; Investigation: Y.Ç.A., K.G.; Material and Methodology: P.B., M.C.B., K.G.; Supervision: Y.Ç.A., K.G., M.C.B.; Visualization: P.B., Y.Ç.A.; Writing-Original Draft: P.B., Y.Ç.A., M.C.B.; Writingreview\&Editing: P.B., Y.Ç.A., M.C.B., K.G.; Other: Y.Ç.A., K.G. All authors have read and agreed to the published version of manuscript.

\section{Conflict of Interest}

The authors have no conflicts of interest to declare.

\section{Funding}

This study has been supported within the scope of project numbered KÜBAP-01/201211 by Kastamonu University, Scientific Research Projects Coordination Department.

\section{References}

Aguirre-Planter, É., Jaramillo-Correa, J. P., Gómez-Acevedo, S., Khasa, D. P., Bousquet, J. \& Eguiarte, L. E. (2012). Phylogeny, diversification rates and species boundaries of Mesoamerican firs (Abies, Pinaceae) in a genus-wide context. Molecular Phylogenetics and Evolution, 62(1), 263-274.

Ateş, M. A. (2011). Molecular phylogenetics of Turkish Abies (pinaceae) species based on matK gene regions of chloroplast genome (Master's thesis, Dept. of Biological Sciences, Middle East Technical University, Ankara).

Davis, P. (1985). PH 1965-1985. Flora of Turkey and the East Aegean Islands. 1-9. Edinburg: Edinburgh University Press.

Fady, B., Arbez, M. \& Marpeau, A. (1992). Geographic variability of terpene composition in Abies cephalonica Loudon and Abies species around the Aegean: hypotheses for their possible phylogeny from the Miocene. Trees-Structure and Function, 6(3), 162-171.
Farjon, A. (1990). Pinaceae. Drawings and descriptions of the genera Abies, Cedrus, Pseudolarix, Keteleeria, Nothotsuga, Tsuga, Cathaya, Pseudotsuga, Larix and Picea. Königstein: Koeltz Scientific Books.

Gülbaba, A. G., Velioğlu, E., Özer, A. S., Doğan, B., Doerksen, A. H. \& Adams, W. T. (1996). Population Genetic Structure of Kazdağ (Abies equitrojani Aschers et Sint.), A Narrow Endemic to Turkey: Implications for in situ Conservation. In Proceedings of the International Symposium of In situ Conservation of Plant Genetic Diversity.

Güner, A., Özhatay, N., Ekim, T. \& Başer, H. K. C. (2000). Flora of Turkey and East Aegean Islands: v.11 Supplement 2. Edinburgh: Edinburgh University Press.

Güner, A., Aslan, S., Ekim, T., Vural, M. \& Babaç, M. (2012). Turkey plant list (vascular plants). İstanbul: Nezahat Gökyiğit Botanical Garden and Flora Research Association Publication.

Hansen, O. K., Kjær, E. D. \& Vendramin, G. (2005). Chloroplast microsatellite variation in Abies nordmanniana and simulation of causes for low differentiation among populations. Tree Genetics \& Genomes, 1(3), 116-123.

Hrivnák, M., Paule, L., Krajmerová, D., Kulaç, Ş., Şevik, H., Turna, İ., ... \& Gömöry, D. (2017). Genetic variation in Tertiary relics: The case of eastern-Mediterranean Abies (Pinaceae). Ecology and Evolution, 7(23), 10018-10030.

Isoda, K., Shiraishi, S. \& Kisanuki, H. (2000). Classifying Abies species (Pinaceae) based on the sequence variation of a tandemly repeated array found in the chloroplast DNA trnL and trnF intergenic spacer. Silvae Genetica, 49(3), 161-164.

Kaya, Z., Skaggs, A. \& Neale, D. B. (2008). Genetic Differentiation of Abies equi-trojani (Asch. \& Sint. ex Boiss) Mattf. populations from Kazdağı, Turkey and the genetic relationship between Turkish Firs belonging to the Abies nordmanniana Spach Complex. Turkish Journal of Botany, 32(1), 1-10.

Kormutak, A., Vookova, B., Ziegenhagen, B., Kwon, H. Y. \& Hong, Y. P. (2004). Chloroplast DNA variation in some representatives of the Asian, North American and Mediterranean firs (Abies spp). Silvae Genetica, 53(1-6), 99-104.

Letunic, I. \& Bork, P. (2016). Interactive tree of life (iTOL) v3: an online tool for the display and annotation of phylogenetic and other trees. Nucleic Acids Research, 44(1), 242-245.

Li, H.L. (1975). Flora of Taiwan, Epoch publishing, 2, 316p., Taiwan. 
Liang, H. (2003). The Phylogenetic Reconstruction of the grass family (Poaceae) using matK gene sequences (Doctoral dissertation, Virginia Polytechnic Institute, Blacksburg).

Özdemir Değirmenci, F. (2011). Molecular phylogenetic position of Turkish abies (pinaceae) based on noncoding trn regions of chloroplast genome (Master's thesis, Dept. of Biological Sciences, Middle East Technical University, Ankara).

Parducci, L. \& Szmidt, A. (1999). PCR-RFLP analysis of cpDNA in the genus Abies. TAG Theoretical and Applied Genetics, 98(5), 802808.

Saghai-Maroof, M.A., Soliman, K.M., Jorgensen, R.A. \& Allard, R. (1984). Ribosomal DNA spacer-length polymorphisms in barley: Mendelian inheritance, chromosomal location, and population dynamics. Proceedings of the National Academy of Sciences, 81(24), 80148018.

Semerikova, S.A., Semerikov, V.L. \& Lascoux, M. (2011). Post-glacial history and introgression in Abies (Pinaceae) species of the Russian Far East inferred from both nuclear and cytoplasmic markers. Journal of Biogeography, 38(2), 326-340.

Semerikova, S.A. \& Semerikov, V.L. (2014). Molecular phylogenetic analysis of the genus Abies (Pinaceae) based on the nucleotide sequence of chloroplast DNA. Russian Journal of Genetics, 50(1), 7-19.

Suyama, Y., Yoshimaru, H. \& Tsumura, Y. (2000). Molecular phylogenetic position of Japanese Abies (Pinaceae) based on chloroplast DNA sequences. Molecular Phylogenetics and Evolution, 16(2), 271-277.

Şimşek, Y. (1992). Türkiye Orijinli Göknar Türlerinin Genetik Yapıları Üzerine Araştırmalar. Ormancılık Araştırma Enstitüsü, Teknik Bülten Serisi (221).

Tamura, K., Stecher, G., Peterson, D., Filipski, A. \& Kumar, S. (2013). MEGA6: molecular evolutionary genetics analysis version 6.0. Molecular Biology and Evolution, 30(12), 2725-2729.

Tayanç, Y., Çengel, B., Kandemir, G. \& Velioğlu, E. (2013). Türkiye'de Yayılış Gösteren Göknar (Abies spp.) Populasyonlarının Genetik Çeşitliliği ve Filogenetik Sinıflandırması. Orman Genel Müdürlüğü Orman Ağaçları ve Tohumları Islah Araştırma Enstitüsü Müdürlüğü Yayınları, (47).

Tozkar, C.Ö., Önde, S. \& Kaya, Z. (2009). The phylogenetic relationship between populations of marginally and sympatrically located Pinus halepensis Mill. and Pinus brutia Ten. in Turkey, based on the ITS-2 region. Turkish Journal of Agriculture and Forestry, 33(4), 363-373.

Wang, X.R., Tsumura, Y., Yoshimaru, H., Nagasaka, K. \& Szmidt, A.E. (1999). Phylogenetic relationships of Eurasian pines (Pinus, Pinaceae) based on chloroplast rbcL, matK, rp120-rps18 spacer, and trnV intron sequences. American Journal of Botany, 86(12), 1742-1753.

Xiang, Q.P., Xiang, Q.Y., Guo, Y.Y. \& Zhang, X.C. (2009). Phylogeny of Abies (Pinaceae) inferred from nrITS sequence data. Taxon, 58(1), 141-152.

Xiang, Q.P., Xiang, Q.Y., Liston, A. \& Zhang, X.C. (2004). Phylogenetic relationships in Abies (Pinaceae): evidence from PCR-RFLP of the nuclear ribosomal DNA internal transcribed spacer region. Botanical Journal of the Linnean Society, 145(4), 425-435.

Ziegenhagen, B., Fady, B., Kuhlenkamp, V. \& Liepelt, S. (2005). Differentiating groups of Abies species with a simple molecular marker. Silvae Genetica, 54(1-6), 123-126. 
Supplement Table 1. The $\mathrm{p}$ distances of Turkish fir taxa members based on the trnR-trnN DNA region.

\begin{tabular}{|c|c|c|c|c|c|c|c|c|c|c|c|c|}
\hline & isau. 4 & isau. 8 & isau. 6 & isau.10 & nord.2 & nord.5 & equi.2 & equi.10 & cili.1 & cili.5 & nord.1 & born.3 \\
\hline \multicolumn{13}{|l|}{ Abies cilicica subsp. isaurica-4 } \\
\hline Abies cilicica subsp. isaurica- 8 & 0.019 & & & & & & & & & & & \\
\hline Abies cilicica subsp. isaurica-6 & 0.070 & 0.063 & & & & & & & & & & \\
\hline Abies clicica subsp. isaurica-10 & 0.007 & 0.023 & 0.071 & & & & & & & & & \\
\hline Abies nordmanniana subsp. nordmanniana-2 & 0.004 & 0.020 & 0.068 & 0.005 & & & & & & & & \\
\hline Abies nordmanninana subsp. nordmanniana-5 & 0.004 & 0.020 & 0.068 & 0.005 & 0.000 & & & & & & & \\
\hline Abies nordmanniana subsp. equi-trojani-2 & 0.004 & 0.020 & 0.068 & 0.005 & 0.000 & 0.000 & & & & & & \\
\hline Abies nordmanniana subsp. equi-trojani-10 & 0.004 & 0.020 & 0.068 & 0.005 & 0.000 & 0.000 & 0.000 & & & & & \\
\hline Abies cilicica subsp. cilicica-1 & 0.005 & 0.022 & 0.070 & 0.005 & 0.004 & 0.004 & 0.004 & 0.004 & & & & \\
\hline Abies cilicica subsp. cilicica-5 & 0.005 & 0.022 & 0.070 & 0.007 & 0.001 & 0.001 & 0.001 & 0.001 & 0.005 & & & \\
\hline Abies nordmanniana subsp. bornтиelleriana-3 & 0.004 & 0.020 & 0.068 & 0.005 & 0.000 & 0.000 & 0.000 & 0.000 & 0.004 & 0.001 & 0.011 & \\
\hline Picea abies & 0.194 & 0.211 & 0.263 & 0.195 & 0.189 & 0.189 & 0.189 & 0.189 & 0.194 & 0.190 & 0.201 & 0.189 \\
\hline
\end{tabular}


Supplement Table 2. The p distances of Turkish fir taxa members and other fir species based on the trnR-trnN DNA region.

\begin{tabular}{|c|c|c|c|c|c|c|c|c|c|c|c|c|c|c|c|c|c|c|c|c|c|c|c|}
\hline \multirow{2}{*}{\multicolumn{24}{|c|}{ holoph fabri forrst. farge. marie. chen. neph. firma grand. iowi. conco. isau. 4 isau. 8 isau. 6 isau. 10 equi. 2 equi. 10 cili.1 }} \\
\hline & & & & & & & & & & & & & & & & & & & & & & & \\
\hline Abies yuanbaoshanensis & 0.002 & & & & & & & & & & & & & & & & & & & & & & \\
\hline Abies lasiocarpa & 0.002 & 20.004 & & & & & & & & & & & & & & & & & & & & & \\
\hline Abies holophylla & 0.002 & 20.000 & 0.004 & & & & & & & & & & & & & & & & & & & & \\
\hline Abies fabri & 0.004 & 40.002 & 0.006 & 0.002 & & & & & & & & & & & & & & & & & & & \\
\hline Abies forrestii & 0.006 & 50.004 & 0.008 & 0.004 & 0.002 & & & & & & & & & & & & & & & & & & \\
\hline Abies fargesii & 0.006 & 50.004 & 0.008 & 0.004 & 0.002 & 0.002 & & & & & & & & & & & & & & & & & \\
\hline Abies mariesii & 0.004 & 0.006 & 0.006 & 0.006 & 0.008 & 0.010 & 0.010 & & & & & & & & & & & & & & & & \\
\hline Abies chensiensis & 0.004 & 0.002 & 0.006 & 0.002 & 0.000 & 0.002 & 0.002 & 0.008 & & & & & & & & & & & & & & & \\
\hline Abies nephrolepis & 0.002 & 0.000 & 0.004 & 0.000 & 0.002 & 0.004 & 0.004 & 0.006 & 0.002 & & & & & & & & & & & & & & \\
\hline Abies firma & 0.002 & 0.000 & 0.004 & 0.000 & 0.002 & 0.004 & 0.004 & 0.006 & 0.002 & 0.000 & & & & & & & & & & & & & \\
\hline Abies grandis & 1.084 & 1.087 & 1.087 & 1.087 & 1.087 & 1.084 & 1.078 & 1.078 & 1.087 & 1.087 & 1.087 & & & & & & & & & & & & \\
\hline Abies lowiana & 1.075 & 1.078 & 1.078 & 1.078 & 1.078 & 1.075 & 1.069 & 1.069 & 1.078 & 1.078 & 1.078 & 0.004 & & & & & & & & & & & \\
\hline Abies concolor & 1.066 & 1.069 & 1.069 & 1.069 & 1.069 & 1.066 & 1.060 & 1.060 & 1.069 & 1.069 & 1.069 & 0.006 & 0.002 & & & & & & & & & & \\
\hline Abies cilicica subsp. isaurica-4 & 0.012 & 0.014 & 0.014 & 0.014 & 0.016 & 0.018 & 0.018 & 0.012 & 0.016 & 0.014 & 0.014 & 1.071 & 1.062 & 1.053 & & & & & & & & & \\
\hline Abies cilicica subsp. isaurica- 8 & 0.034 & 0.036 & 0.036 & 0.036 & 0.038 & 0.040 & 0.040 & 0.034 & 0.038 & 0.036 & 0.036 & 1.093 & 1.084 & 1.075 & 0.026 & & & & & & & & \\
\hline Abies cilicica subsp. isaurica-6 & 0.094 & 0.096 & 0.096 & 0.096 & 0.098 & 0.100 & 0.100 & 0.094 & 0.098 & 0.096 & 0.096 & 1.227 & 1.216 & 1.206 & 0.085 & 0.078 & & & & & & & \\
\hline Abies clicica subsp. isaurica-10 & 0.012 & 0.014 & 0.014 & 0.014 & 0.016 & 0.018 & 0.018 & 0.012 & 0.016 & 0.014 & 0.014 & 1.080 & 1.071 & 1.062 & 0.004 & 0.024 & 0.080 & & & & & & \\
\hline $\begin{array}{l}\text { Abies nordmanniana subsp. equi- } \\
\text { trojani-2 }\end{array}$ & 0.008 & 0.010 & 0.010 & 0.010 & 0.012 & 0.014 & 0.014 & 0.008 & 0.012 & 0.010 & 0.010 & 1.077 & 1.068 & 1.059 & 0.004 & 0.026 & 0.085 & 0.002 & & & & & \\
\hline $\begin{array}{l}\text { Abies nordmanniana subsp. equi- } \\
\text { trojani-10 }\end{array}$ & 0.008 & 0.010 & 0.010 & 0.010 & 0.012 & 0.014 & 0.014 & 0.008 & 0.012 & 0.010 & 0.010 & 1.077 & 1.068 & 1.059 & 0.004 & 0.026 & 0.085 & 0.002 & 0.000 & & & & \\
\hline Abies cilicica subsp. cilicica-1 & 0.012 & 0.014 & 0.014 & 0.014 & 0.016 & 0.018 & 0.018 & 0.012 & 0.016 & 0.014 & 0.014 & 1.080 & 1.071 & 1.062 & 0.004 & 0.022 & 0.083 & 0.002 & $0.004 \quad 0.004$ & & & & \\
\hline Abies cilicica subsp. cilicica-5 & 0.008 & 0.010 & 0.010 & 0.010 & 0.012 & 0.014 & 0.014 & 0.008 & 0.012 & 0.010 & 0.010 & 1.077 & 1.068 & 1.059 & 0.004 & 0.026 & 0.085 & 0.002 & $\begin{array}{lll}0.000 & 0.000 \\
\end{array}$ & 0.004 & & & \\
\hline $\begin{array}{l}\text { Abies nordmanniana subsp. } \\
\text { nordmanniana-1 }\end{array}$ & 0.012 & 0.014 & 0.014 & 0.014 & 0.016 & 0.018 & 0.018 & 0.012 & 0.016 & 0.014 & 0.014 & 1.077 & 1.068 & 1.059 & 0.008 & 0.024 & 0.080 & 0.004 & $0.004 \quad 0.004$ & 0.006 & 0.004 & & \\
\hline $\begin{array}{l}\text { Abies nordmanninana subsp. } \\
\text { bornmulleriana-3 }\end{array}$ & 0.008 & 0.010 & 0.010 & 0.010 & 0.012 & 0.014 & 0.014 & 0.008 & 0.012 & 0.010 & 0.010 & 1.077 & 1.068 & 1.059 & 0.004 & 0.026 & 0.085 & 0.002 & $0.000 \quad 0.000$ & 0.004 & 0.000 & 0.004 & \\
\hline
\end{tabular}


Supplement Table 3. The $\mathrm{p}$ distances of Turkish fir taxa members based on the rps18-rpl20 DNA region.

\begin{tabular}{|c|c|c|c|c|c|c|c|c|c|c|c|c|c|c|}
\hline & isau. 8 & isau. 3 & isau. 9 & born.2 & born.10 & born.11 & born.5 & equi.1 & equi. 8 & equi. 5 & equi.7 & cili.10 & isau & isau.1 \\
\hline \multicolumn{15}{|l|}{ Abies cilicica subsp. isaurica -8} \\
\hline Abies cilicica subsp. isaurica -3 & 0.060 & & & & & & & & & & & & & \\
\hline Abies cilicica subsp. isaurica-9 & 0.057 & 0.020 & & & & & & & & & & & & \\
\hline Abies nordmanniana subsp. bornmuelleriana -2 & 0.055 & 0.020 & 0.002 & & & & & & & & & & & \\
\hline Abies nordmanniana subsp. bornmuelleriana -10 & 0.063 & 0.026 & 0.000 & 0.008 & & & & & & & & & & \\
\hline Abies nordmanniana subsp. bornmuelleriana -11 & 0.055 & 0.020 & 0.002 & 0.004 & 0.007 & & & & & & & & & \\
\hline Abies nordmanniana subsp. bornmuelleriana -5 & 0.058 & 0.022 & 0.026 & 0.004 & 0.033 & 0.029 & & & & & & & & \\
\hline Abies nordmanniana subsp. equi-trojan i-1 & 0.055 & 0.018 & 0.012 & 0.012 & 0.017 & 0.010 & 0.015 & & & & & & & \\
\hline Abies nordmanniana subsp. equi-trojani -8 & 0.055 & 0.020 & 0.009 & 0.002 & 0.015 & 0.011 & 0.022 & 0.012 & & & & & & \\
\hline Abies nordmanniana subsp. equi-trojani -5 & 0.055 & 0.020 & 0.030 & 0.004 & 0.035 & 0.031 & 0.017 & 0.012 & 0.024 & & & & & \\
\hline Abies nordmanniana subsp. equi-trojani -7 & 0.056 & 0.020 & 0.006 & 0.002 & 0.009 & 0.007 & 0.032 & 0.012 & 0.009 & 0.028 & & & & \\
\hline Abies cilicica subsp. cilicica -10 & 0.055 & 0.007 & 0.000 & 0.000 & 0.007 & 0.000 & 0.002 & 0.000 & 0.000 & 0.000 & 0.000 & & & \\
\hline Abies cilicica subsp. isaurica & 0.055 & 0.020 & 0.024 & 0.002 & 0.031 & 0.028 & 0.002 & 0.013 & 0.020 & 0.015 & 0.030 & 0.000 & & \\
\hline Abies cilicica subsp. isaurica -1 & 0.058 & 0.022 & 0.004 & 0.004 & 0.011 & 0.002 & 0.009 & 0.006 & 0.004 & 0.004 & 0.004 & 0.002 & 0.006 & \\
\hline Keteleeria davidiana & 0.123 & 0.088 & 0.058 & 0.064 & 0.058 & 0.061 & 0.084 & 0.074 & 0.070 & 0.091 & 0.065 & 0.071 & 0.083 & 0.074 \\
\hline
\end{tabular}


Supplement Table 4. The p distances of Turkish fir taxa members and other fir species based on the rps18-rpl20 DNA region.

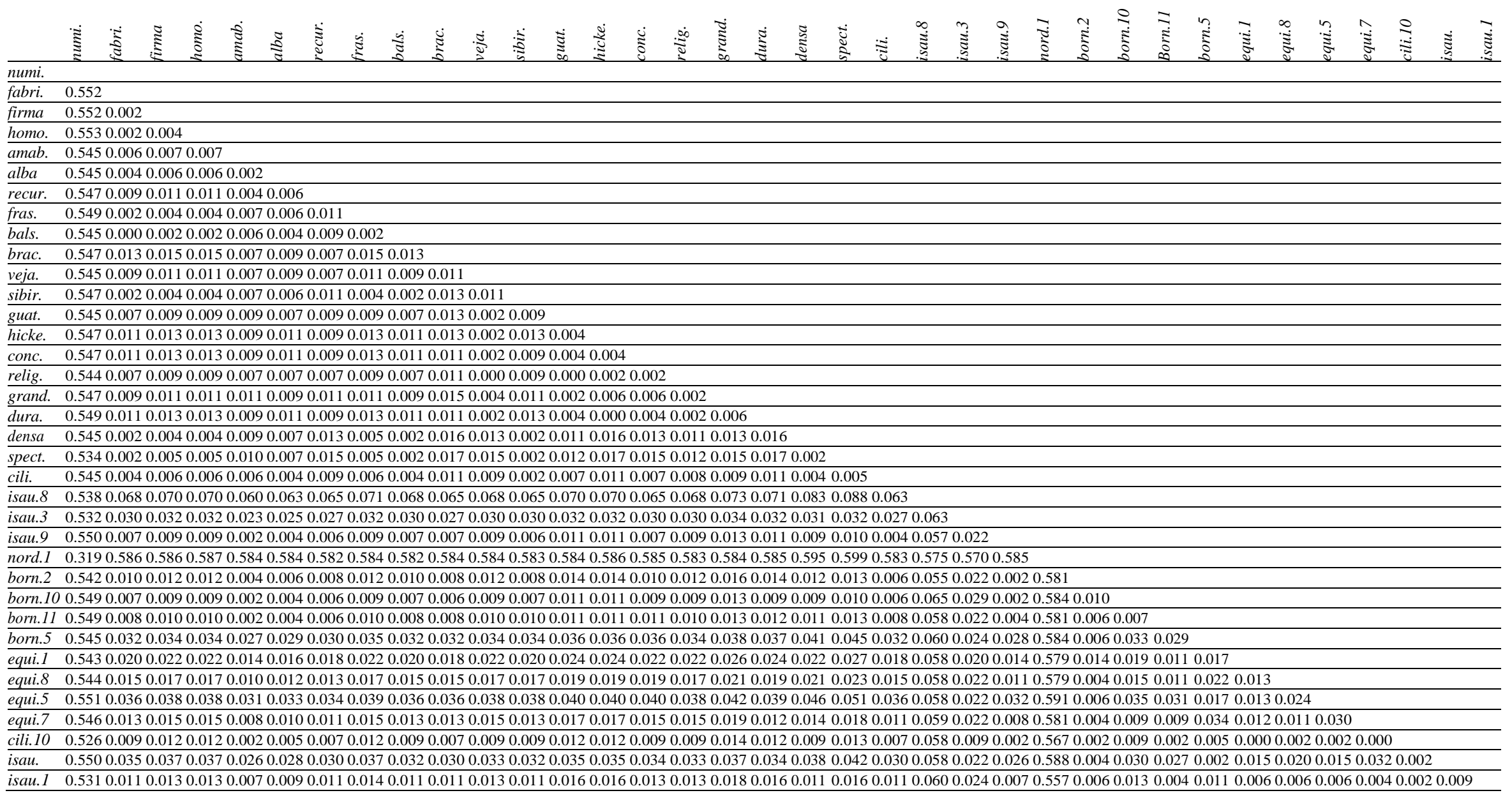

